\title{
Choroid plexus genes for CSF production and brain homeostasis are altered in Alzheimer's disease
}

Shawn Kant ${ }^{1}$, Edward G. Stopa', Conrad E. Johanson², Andrew Baird ${ }^{3}$ and Gerald D. Silverberg ${ }^{4 *}$

\begin{abstract}
Background: The roles of the choroid plexus (CP) and cerebrospinal fluid (CSF) production have drawn increasing attention in Alzheimer's disease (AD) research. Specifically, studies document markedly decreased CSF production and turnover in moderate-to-severe AD. Moreover, reduced CP function and CSF turnover lead to impaired clearance of toxic metabolites, likely promote neuroinflammation, and may facilitate neuronal death during AD progression. We analyzed CP gene expression in AD compared with control subjects, specifically considering those genes involved with CSF production and CP structural integrity.
\end{abstract}

Methods: The Brown-Merck Gene Expression Omnibus (GEO) database (CP transcripts) was mined to examine changes in gene expression in AD compared to controls with a focus on assorted genes thought to play a role in CSF production. Specifically, genes coding for ion transporters in CP epithelium (CPE) and associated enzymes like Na-KATPase and carbonic anhydrase, aquaporins, mitochondrial transporters/enzymes, blood-cerebrospinal fluid barrier (BCSFB) stability proteins, and pro-inflammatory mediators were selected for investigation. Data were analyzed using $t$ test $p$-value and fold-change analysis conducted by the GEO2R feature of the GEO database.

Results: Significant expression changes for several genes were observed in AD CP. These included disruptions to ion transporters (e.g., the solute carrier gene SLC4A5, $p=0.004$ ) and associated enzyme expressions (e.g., carbonic anhydrase CA4, $p=0.0001$ ), along with decreased expression of genes involved in BCSFB integrity (e.g., claudin CLDN5, $p=0.039$ ) and mitochondrial ATP synthesis (e.g., adenosine triphosphate ATP5L, $P=0.0004$ ). Together all changes point to disrupted solute transport at the blood-CSF interface in AD. Increased expression of pro-inflammatory (e.g., interleukin IL1RL1, $p=0.00001$ ) and potential neurodegenerative genes (e.g., amyloid precursor APBA3, $p=0.002$ ) also implicate disturbed CP function.

Conclusions: Because the altered expression of numerous transcripts in AD-CP help explain decreased CSF production in $A D$, these findings represent a first step towards identifying novel therapeutic targets in $A D$.

Keywords: CSF production, Homeostasis, Blood-CSF barrier, Blood-brain barrier, Choroid plexus Gene Expression Omnibus, Solute carrier families, Choroidal tight junctions, Barrier permeability, Choroid plexus transcriptome, Beta amyloid, Mitochondria

\footnotetext{
*Correspondence: geralds@stanford.edu

${ }^{4}$ Department of Neurosurgery, Stanford University, 710 Frenchmans Rd,

Stanford, CA 94305, USA

Full list of author information is available at the end of the article
} 


\section{Background}

Alzheimer's disease (AD) is a neurodegenerative disorder marked by cognitive, memory and behavioral impairment that significantly interferes with social and occupational functioning. It is an incurable disease, at present, with a long preclinical period and progressive course. In $\mathrm{AD}$, amyloid-beta $(\mathrm{A} \beta)$ peptide plaques develop in the hippocampus, and in other areas of the cerebral cortex. Whether plaques themselves cause AD or whether they are a by-product of the AD process remains unknown.

The roles of the blood-cerebrospinal fluid (CSF) barrier (BCSFB) and CSF itself in the pathogenesis of $\mathrm{AD}$ are receiving increasing attention [1-5]. Like the bloodbrain barrier (BBB), the BCSFB functions as a transport interface, facilitating exchange of solutes and $\mathrm{H}_{2} \mathrm{O}$ between plasma and CSF [6]. The four choroid plexuses $(\mathrm{CP})$, one in each ventricle, are the anatomic substrate of the BCSFB and are responsible for more than $60-75 \%$ of CSF production [7] with the remainder produced by the ventricular ependyma and $\mathrm{BBB}$. At the cellular level, $\mathrm{CP}$ epithelium (CPE) cells are continuous with the ventricular ependymal layer and have apical microvilli. However, unlike the tight junctions of the BBB between capillary endothelial cells, the tight junctions of the BCSFB are located only at the apical portion of the CPE. In humans, normal CSF secretion ranges from 400 to $600 \mathrm{ml} /$ day [1, 7].

Production of CSF by CP occurs in two major sequential steps: passive fluid ultrafiltration across $\mathrm{CP}$ capillaries and active ion transport across the CPE [7, 8]. A pressure gradient first filters plasma from choroidal capillaries into the interstitial compartment of the $\mathrm{CP}$ [9]. Carbonic anhydrases catalyze conversion of $\mathrm{H}_{2} \mathrm{O}$ and $\mathrm{CO}_{2}$ to $\mathrm{H}^{+}$ and $\mathrm{HCO}_{3}^{-}$ions. Ion co-transporters and exchangers translocate $\mathrm{Na}^{+}, \mathrm{K}^{+}, \mathrm{Cl}^{-}$, and $\mathrm{HCO}_{3}{ }^{-}$ions from the interstitial fluid across the basolateral membrane into the CPE cell and then, after cytoplasmic swirling, across the apical membrane into the ventricles by energy-dependent active transport [10-15]. Water flows across the CPE from plasma to ventricular lumen (e.g., through aquaporins) in concordance with prevailing osmotic solute gradients [16].

Considerable neurodegeneration research has focused on increased BBB permeability and decreased efficiency of $A \beta$ peptide clearance across the $\mathrm{BBB}$ in aging and in $\mathrm{AD}$ [17-19]. Interestingly, just as in the BBB, tight junctions in $\mathrm{CP}$ lose integrity during $\mathrm{AD}$ progression. This is consistent with increased paracellular permeability and BCSFB breaching [20, 21]. Indeed, many of the structural changes that occur in the $\mathrm{AD} \mathrm{CP}$ are among the first signs of the disease in a subset of patients, including extensive atrophy of the CPE that resembles analogous changes seen in accelerated aging [20].
Clinical evidence also points to significantly decreased CSF production rates in moderate-to-severe stages of $\mathrm{AD}$ versus normal controls [1]. For example, CSF production is $\sim 1 / 2$ normal and CSF turnover, defined as the volume of CSF produced in $24 \mathrm{~h}$ divided by the volume of the CSF space, is reduced by threefold, from four times to once per day in $\mathrm{AD}$ subjects compared to age-matched controls $[1,2]$.

Current theory suggests that CSF hydrostatic pressure initially rises during early $\mathrm{AD}$ before falling again in later-stage $\mathrm{AD}$, as reduced CSF production outpaces the decreased CSF absorption [22]. Decreased CSF production and turnover in $\mathrm{AD}$ have significant consequences for removing toxic metabolites from the CNS. For example, altered CPE cholesterol metabolism may affect $A \beta$ clearance from CSF [23]. Diminished CSF production also decreases the ability of CP-secreted transthyretin (TTR) to circulate throughout the CNS via the CSF and bind to and stabilize $A \beta$ deposits [20].

Taken together, these findings highlight the need to elucidate gene-linked predisposition to pathology in $\mathrm{CP}, \mathrm{CSF}$, and BCSFB, and how modified transcript production adversely affects CP-CSF solute homeostasis and neuropathology. Of particular interest are the specific genetic factors behind impaired CSF production and turnover in $\mathrm{AD}$. We investigated genes known to be involved in these processes for expression differences between healthy and AD-affected CP. These data inform on genes that most strongly affect the outcome of CSF production and potentially have the strongest impact on $\mathrm{AD}$ pathology progression in the CP-CSF-brain system.

\section{Methods}

A choroid plexus Gene Expression Omnibus (GEO) database archived at https://www.ncbi.nlm.nih.gov/geo/ query/acc.cgi?acc $=$ GSE110226 under the GEO accession number GSE110226 was mined for gene expression differences between choroid plexus from control and $A D$ subject brains.

\section{Subject matter}

The Brown-Merck database was created using transcriptome-wide Affymetrix microarray assays (Affymetrix, Santa Clara, CA, USA) to examine gene expression via extracted RNA from human CP tissue samples [24]. RNA was extracted with TRIzol reagent by the Thermo-Fisher protocol (Thermo-Fisher, Grand Island, NY, USA). Lateral ventricle $\mathrm{CP}$ tissue samples were taken from six control cases, seven late-stage AD cases, four frontotemporal dementia cases, and three Huntington's disease cases. Tissue samples were post-mortem, mean post mortem interval (PMI) of $22 \mathrm{~h}$ for controls, $17 \mathrm{~h}$ for AD. Until processing could occur, tissues were snap frozen in liquid 
nitrogen and stored at $-80{ }^{\circ} \mathrm{C}$ at the Brown University Brain Tissue for Neurodegenerative Disorders Resource Center. For this study, we only mined data for gene expression level differences between control and $\mathrm{AD}$ cases. AD cases were slightly older than controls. This is an advantage because older people and those with early AD often show no significant differences in gene expression (personal observation by author EGS from prior gene studies).

Genes of interest (GoI) were selected based on their known or purported significance to $\mathrm{CP}$ function and/ or CSF production. For example, genes and mRNA that express solute transporters in CPE are integral to CSF production [25]. Specifically, genes involved in the active transport of ions (along with the obligatory transport of $\mathrm{H}_{2} \mathrm{O}$ ) from blood to the ventricular lumen are the final pathway of CSF production; these are considered ratelimiting genes. Therefore we focus considerable attention on genes for $\mathrm{Na}-\mathrm{K}-\mathrm{ATPa} e$, the $\mathrm{Na}-\mathrm{K}-\mathrm{Cl}$ cotransporter, and other components of this final secretory pathway.

GoI involved in mitochondrial ATP synthesis and ion transport were also selected. Without sufficient mitochondrial energy production, the active ion transporters in CP cannot operate normally. Intracellular bicarbonate production facilitates $\mathrm{HCO}_{3}^{-}$-dependent $\mathrm{Na}^{+}$and $\mathrm{Cl}^{-}$ exchange across the CPE [26-29]. In this vein, we consider the carbonic anhydrase family, along with several members of the solute carrier (SLC) gene family responsible for $\mathrm{HCO}_{3}{ }^{-}$exchange and transport. Genes encoding BCSFB structural elements for maintenance of regulated solute transport were considered as well, along with proinflammatory and neurodegenerative genes capable of damaging the BCSFB.

\section{Statistical methods}

Gene expression differences between control and $\mathrm{AD}$ samples in the database were determined using the GEO2R search feature of the GEO database. This approach creates different groups of samples based on unifying characteristics for each group. GEO2R then generates statistics for gene expression comparisons between groups. Examining visual profiles depicting mRNA expression levels for each sample in the $\mathrm{AD}$ versus control groups generated by GEO2R, allowed visualization of upregulation versus downregulation of various genes in AD compared with control CP tissue.

The Brown-Merck database was first mined to identify which specific genes involved in CSF production and CP function differed in expression between control and $\mathrm{AD}$ samples. Separate tables were then composed for genes that were upregulated, downregulated or unchanged in AD. Significance was assessed with t-test $p$ value analyses of each gene. An $\alpha$ of $<0.05$ was deemed significant. The sign of the moderated $t$ statistic of each gene confirmed the direction of gene expression changes (upregulation or downregulation) seen in the visual mRNA expression profiles.

Fold changes to quantify the magnitude of gene expression differences between control and $\mathrm{AD}$ groups were determined through GEO2R log base 2 fold change (log2 FC) analysis, reported as $\log 2 \mathrm{FC}$ values. GEO2R took the difference between $\log 2$ of the gene expression value of a given gene in the control group and $\log 2$ of the gene expression value of that same given gene in the $\mathrm{AD}$ group to produce $\log 2 \mathrm{FC}$ in the tables. Hence positive $\log 2 \mathrm{FC}$ values signify downregulation in $\mathrm{AD}$ relative to control and negative $\log 2 \mathrm{FC}$ values signify upregulation in $\mathrm{AD}$ relative to control. Additional file 1 gives actual gene expression values for each gene studied.

\section{Results}

We investigated expression levels of several different genes and gene families that are purported to impact $\mathrm{CP}$ structural integrity and CSF production. The SLC family of genes, for example, appears responsible for considerable ion and $\mathrm{H}_{2} \mathrm{O}$ transport across CPE [25]. Within the SLC group, there was diversified expression in control versus $\mathrm{AD}$. Certain genes for $\mathrm{HCO}_{3}{ }^{-}$exchange and cotransport (SLC4 subfamily) had decreased expression in $\mathrm{AD}$, including SLC4A10 $(\mathrm{p}=0.028, \log 2 \mathrm{FC}=0.039)$ and SLC4A5 $(\mathrm{p}=0.004, \log 2 \mathrm{FC}=1.12)$. Other SLC genes with decreased expression include the $\mathrm{Na}-\mathrm{K}-\mathrm{Cl}$ cotransporters SLC12A1 $(\mathrm{p}=0.035, \log 2 \mathrm{FC}=1.05)$ and SLC12A2 $(\mathrm{p}=0.005, \log 2 \mathrm{FC}=0.38)$. Table 1 compiles downregulated $\mathrm{CP}$ genes in the Brown-Merck database relevant to CSF production, energy production and $\mathrm{CP}$ structural integrity. Included in each table is the foldchange ( $\log 2 \mathrm{FC}$ ) in expression between $\mathrm{AD}$ and control.

Among the upregulated SLC genes in AD CP were mitochondrial Fe transporters: SLC25A37 $(\mathrm{p}=0.0001$, $\log 2 \mathrm{FC}=-0.64) \quad$ and $\quad$ SLC25A28 $\quad(\mathrm{p}=0.0001$, $\log 2 \mathrm{FC}=-0.64)$. Other ion-transporters, like the $\mathrm{KCC} 4 \mathrm{~K}-\mathrm{Cl}$ cotransporter SLC12A6 $(\mathrm{p}=0.026$, $\log 2 \mathrm{FC}=-0.67)$ and the organic anion clearance transporter SLCO4A1 $(\mathrm{p}=0.0001, \log 2 \mathrm{FC}=-1.85)$, were upregulated in AD. Table 2 lists upregulated genes, from the Brown-Merck database, involved in CSF production.

The Na-K-ATPase significantly impacts CSF production [13]. Na-K-ATPase is a major pathway for $\mathrm{Na}^{+}$ secretion into CSF (and $\mathrm{K}^{+}$uptake from CSF) [26]. The Na-K-ATPase transporting subunit $\alpha 2$, ATP1A2 $(\mathrm{p}=0.04, \log 2 \mathrm{FC}=0.51)$, and the Na-K-ATPase transporting subunit $\beta 1, \operatorname{ATP} 1 B 1(p=0.04, \log 2 \mathrm{FC}=0.29)$, were downregulated in AD. Of all ATPase genes investigated, only ATP1A1 $(\mathrm{p}=0.02, \log 2 \mathrm{FC}=-0.45)$, the transporting subunit $\alpha 1$, was upregulated in $\mathrm{AD}$. 
Table 1 Genes downregulated in AD CP

\begin{tabular}{|c|c|c|c|c|}
\hline Gene symbol & Gene name & p-value & $\begin{array}{l}\text { t-value (control } \\
\text { relative to } A D \text { ) }\end{array}$ & Log2 fold change \\
\hline \multicolumn{5}{|l|}{ SLC family } \\
\hline SLC26A2 & Solute carrier family 26 member 2; sulfate transporter & 0.0000313 & 5.88360095 & 1.43830952 \\
\hline SLC5A5 & Solute carrier family 5 member 5 ; sodium/iodine cotransporter & 0.0000375 & 5.78520397 & 0.75760238 \\
\hline SLC4A10 & Solute carrier family 4 member 10: Na-dependent $\mathrm{Cl}-\mathrm{HCO} 3$ exchanger & 0.0275 & 2.44489236 & 0.39339524 \\
\hline SLC4A5 & Solute carrier family 4 member 5 : $\mathrm{Na}-\mathrm{HCO} 3$ exchanger & 0.00366 & 3.44425553 & 1.1215619 \\
\hline SLC12A1 & Solute carrier family 12 member 1: NKCC2 Na-K-Cl cotransporter & 0.0353 & 2.31563648 & 1.05009524 \\
\hline $\mathrm{SLC} 12 \mathrm{~A} 2$ & Solute carrier family 12 member 2: NKCC1 Na-K-Cl cotransporter & 0.00517 & 3.27527462 & 0.38004286 \\
\hline \multicolumn{5}{|c|}{ Na-K ATPase family } \\
\hline ATP1A2 & Na-K ATPase transporting subunit alpha 2 & 0.0387 & 2.26741686 & 0.50910238 \\
\hline ATP1B1 & Na-K ATPase transporting subunit beta 1 & 0.0429 & 2.21376353 & 0.29179286 \\
\hline \multicolumn{5}{|c|}{ Carbonic anhydrase family } \\
\hline CA4 & Carbonic anhydrase 4 & 0.000139 & 5.08319761 & 0.63055238 \\
\hline CA2 & Carbonic anhydrase 2 & 0.0222 & 2.55323972 & 0.30442619 \\
\hline CA3 & Carbonic anhydrase 3 & 0.0391 & 2.26309122 & 0.58876429 \\
\hline \multicolumn{5}{|c|}{ ATP synthase family } \\
\hline ATP5L & ATP synthase, $\mathrm{H}+$ transporting, mitochondrial Fo complex subunit $\mathrm{G}$ & 0.000419 & 4.51769377 & 0.44282857 \\
\hline ATP23 & ATP23 metallopeptidase and ATP synthase assembly factor homolog & 0.000780 & 4.20573756 & 0.62625 \\
\hline ATP5G3 & ATP synthase, $\mathrm{H}+$ transporting, mitochondrial Fo complex subunit $\mathrm{C} 3$ (subunit 9) & 0.00154 & 3.86838238 & 0.65084286 \\
\hline ATPAF1 & ATP synthase mitochondrial F1 complex assembly factor 1 & 0.00269 & 3.59573018 & 0.56412619 \\
\hline ATP5B & ATP synthase, $\mathrm{H}+$ transporting, mitochondrial F1 complex, beta polypeptide & 0.0107 & 2.91564259 & 0.45252381 \\
\hline \multicolumn{5}{|c|}{ Tight junction claudins } \\
\hline CLDN18 & Claudin-18 & 0.0105 & 2.92789759 & 0.46640476 \\
\hline CLDN11 & Claudin-11 & 0.0190 & 2.63115902 & 0.64749762 \\
\hline CLDN5 & Claudin-5 & 0.0399 & 2.25235984 & 0.70879524 \\
\hline \multicolumn{5}{|l|}{ Others } \\
\hline APP & Amyloid beta precursor protein & 0.0144 & 2.77007349 & 0.41097857 \\
\hline
\end{tabular}

Positive $t$ values for comparisons represent gene changes decreased in AD relative to control (i.e. increased in control relative to AD). The same is true for positive $\log 2 \mathrm{FC}$ values

Another gene family integral to CSF production and homeostasis is carbonic anhydrase (CA). CA catalyzes production of $\mathrm{HCO}_{3}{ }^{-}$and $\mathrm{H}^{+}$from $\mathrm{H}_{2} \mathrm{O}$ and $\mathrm{CO}_{2}$ [26]. $\mathrm{HCO}_{3}{ }^{-}$is essential to $\mathrm{CPE}$ transport processes; thus proper generation of $\mathrm{HCO}_{3}{ }^{-}$by CA in CPE is vital to the ability of the CP to secrete CSF [27]. Isoforms showed diverse up- and downregulation in $\mathrm{AD}$. CA2 $(\mathrm{p}=0.022$, $\log 2 \mathrm{FC}=0.30), \mathrm{CA} 3(\mathrm{p}=0.039, \log 2 \mathrm{FC}=0.59)$, and $\mathrm{CA} 4$ $(\mathrm{p}=0.0001, \log 2 \mathrm{FC}=0.63)$ were downregulated. However, CA13 ( $\mathrm{p}=0.015, \log 2 \mathrm{FC}=-0.51)$ was upregulated. Other CA gene transcripts were not significantly altered.

Barrier-stabilizing genes of the claudin family, CLDN5 $(\mathrm{p}=0.04, \log 2 \mathrm{FC}=0.71)$, CLDN18 $(\mathrm{p}=0.011$, $\log 2 \mathrm{FC}=0.47)$ and CLDN11 $(\mathrm{p}=0.019, \log 2 \mathrm{FC}=0.65)$, were downregulated in AD. For several other claudin genes known or purported to be involved in epithelial tight junctions, a tendency towards downregulation was observed, although results lacked significance. Also downregulated was $A \beta$ precursor protein, APP $(\mathrm{p}=0.014, \log 2 \mathrm{FC}=0.41)$. However, other CP APP genes (e.g., $\mathrm{APBA} 3, \quad \mathrm{p}=0.0015, \quad \log 2 \mathrm{FC}=-0.51$ ) were upregulated. Subunits and assembly factors of the mitochondrial F0F1 ATP synthase, an important source of ATP synthesis, such as ATP5L $(p=0.0004$, $\log 2 \mathrm{FC}=0.44)$ and ATP23 $(\mathrm{p}=0.0008, \log 2 \mathrm{FC}=0.63)$ were downregulated in AD CP. We observed no significant changes in expression of aquaporin 4, and aquaporin 1 (a known passageway for passive flow of $\mathrm{H}_{2} \mathrm{O}$ from CPE to ventricular lumen).

Tables 3 and 4 list genes that did not display significant changes in expression levels between $\mathrm{AD}$ and control groups, but displayed tendencies towards upregulation and downregulation that may be of interest for future studies.

The large number of significantly altered $\mathrm{CP}$ genes, for barrier stability, solute and $\mathrm{H}_{2} \mathrm{O}$ transport, and production of ATP to energize transport, makes it unlikely that CSF production is maintained normally in AD. 
Table 2 Genes upregulated in AD CP

\begin{tabular}{|c|c|c|c|c|}
\hline Gene symbol & Gene name & $p$-value & $\begin{array}{l}\text { t-value (control } \\
\text { relative to } A D \text { ) }\end{array}$ & Log2 fold change \\
\hline \multicolumn{5}{|l|}{ SLC family } \\
\hline SLC25A37 & Solute carrier family 25 member 37: mitochondrial iron transporter & 0.000128 & -5.12740967 & -0.64122381 \\
\hline SLC25A28 & Solute carrier family 25 member 28 ; mitochondrial iron transporter & 0.0000927 & -5.29698098 & -0.64098333 \\
\hline SLCO4A1 & $\begin{array}{l}\text { Solute carrier organic anion transporter family member } 4 \mathrm{~A} 1 \text {; organic } \\
\text { anion transporter }\end{array}$ & 0.000103 & -5.24167279 & -1.85499048 \\
\hline SLC12A7 & Solute carrier family 12 member $7 ; \mathrm{KCC} 4 \mathrm{~K}-\mathrm{Cl}$ cotransporter & 0.000741 & -4.23121588 & -0.67435 \\
\hline SLC12A6 & Solute carrier family 12 member 6 ; $\mathrm{KCC} 3 \mathrm{~K}-\mathrm{Cl}$ cotransporter & 0.0262 & -2.46864419 & -0.52261429 \\
\hline \multicolumn{5}{|c|}{ Interleukin-1-receptor family } \\
\hline IL1R1 & Interleukin-1 receptor & 0.0185 & -2.64459755 & -0.62269524 \\
\hline IL1RL1 & Interleukin 1 receptor-like 1 & 0.0000113 & -6.45879688 & -3.43624762 \\
\hline \multicolumn{5}{|c|}{ Carbonic anhydrase family } \\
\hline CA13 & Carbonic anhydrase 13 & 0.0152 & -2.74368279 & -0.51382619 \\
\hline \multicolumn{5}{|c|}{ Na-K ATPase family } \\
\hline ATP1A1 & Na-K ATPase transporting subunit alpha 1 & 0.0198 & -2.61012511 & -0.45077857 \\
\hline \multicolumn{5}{|c|}{ Amyloid proteins } \\
\hline ABPA3 & Amyloid beta precursor protein (APP) binding family A member 3 & 0.00154 & -3.86960931 & -0.51001667 \\
\hline APBB1IP & APP binding family $B$ member 1 interacting protein & 0.0116 & -2.87838249 & -0.53602143 \\
\hline
\end{tabular}

Negative $t$ values are for comparisons displaying gene changes that are increased in AD relative to control (i.e. decreased in control relative to $A D)$. The same is true for negative $\log 2 \mathrm{FC}$ values

Table 3 Unchanged genes with possible tendency of downregulation in AD CP

\begin{tabular}{|c|c|c|c|c|}
\hline Gene symbol & Gene name & p-value & $\begin{array}{l}\text { t-value (control } \\
\text { relative to } A D \text { ) }\end{array}$ & Log2 fold change \\
\hline \multicolumn{5}{|l|}{ SLC family } \\
\hline SLC12A4 & Solute carrier family 12 member 4 : $\mathrm{KCC} 1 \mathrm{~K}-\mathrm{Cl}$ cotransporter & 0.0947 & 1.78492648 & 0.23569524 \\
\hline SLC4A2 & Solute carrier family 4 member 2: $\mathrm{Cl}-\mathrm{HCO} 3$ exchanger & 0.130 & 1.60190388 & 0.21841905 \\
\hline SLC38A3 & Solute carrier family 38 member 3 ; system $\mathrm{N}$ amino acid transporter & 0.223 & 1.27232445 & 0.2807 \\
\hline \multicolumn{5}{|c|}{ Na-K ATPase family } \\
\hline ATP1B2 & Na-K ATPase transporting subunit beta 2 & 0.0533 & 2.09928405 & 0.39634524 \\
\hline ATP1A4 & Na-K ATPase transporting subunit alpha 4 & 0.684 & 0.41463513 & 0.06897143 \\
\hline \multicolumn{5}{|c|}{ Carbonic anhydrase family } \\
\hline CA8 & Carbonic anhydrase 8 & 0.138 & 1.56854024 & 0.50962619 \\
\hline CA14 & Carbonic anhydrase 14 & 0.172 & 1.4334038 & 0.29066667 \\
\hline \multicolumn{5}{|c|}{ Tight junction claudins and occludin } \\
\hline CLDN1 & Claudin-1 & 0.188 & 1.37904737 & 0.35589048 \\
\hline CLDN2 & Claudin-2 & 0.161 & 1.47424712 & 0.43342857 \\
\hline CLDN3 & Claudin-3 & 0.0942 & 1.78793258 & 0.41007381 \\
\hline CLDN19 & Claudin-19 & 0.375 & 0.91449198 & 0.32223095 \\
\hline OCLN & Occludin & 0.799 & 0.25905032 & 0.03019762 \\
\hline \multicolumn{5}{|l|}{ Others } \\
\hline AQP4 & Aquaporin 4 & 0.621 & 0.50457389 & 0.18047619 \\
\hline
\end{tabular}

Positive $t$ values for comparisons represent gene changes decreased in AD relative to control (i.e. increased in control relative to AD). The same is true for positive $\log 2 \mathrm{FC}$ values

\section{Discussion}

The basic requirements for CSF production are (i) transport of ions and $\mathrm{H}_{2} \mathrm{O}$ from $\mathrm{CPE}$ to the ventricular CSF space, (ii) production of energy to facilitate that active transport and (iii) an intact CP. Analysis of our BrownMerck GEO database revealed significantly-altered gene expression in $\mathrm{AD} \mathrm{CP}$ that adversely impacts the physiology necessary for CSF secretion. Genes for ion 
Table 4 Unchanged genes with possible tendency of upregulation in AD CP

\begin{tabular}{|c|c|c|c|c|}
\hline Gene symbol & Gene name & p-value & $\begin{array}{l}\text { t-value (control relative } \\
\text { to } A D \text { ) }\end{array}$ & Log2 fold change \\
\hline \multicolumn{5}{|l|}{ SLC family } \\
\hline SLC39A4 & $\begin{array}{l}\text { Solute carrier family } 39 \text { member 4; ZIP4 } \\
\text { metal ion transporter }\end{array}$ & 0.806 & -0.25019879 & -0.03455714 \\
\hline \multicolumn{5}{|c|}{ Carbonic anhydrase family } \\
\hline CA7 & Carbonic anhydrase 7 & 0.310 & -1.05004961 & -0.16493333 \\
\hline CA5B & Carbonic anhydrase 5B & 0.149 & -1.5231615 & -0.23130952 \\
\hline CA11 & Carbonic anhydrase 11 & 0.445 & -0.78401027 & -0.1202119 \\
\hline \multicolumn{5}{|l|}{ Other genes } \\
\hline PSEN1 & Presenilin 1 & 0.0687 & -1.96233878 & -0.23186667 \\
\hline PSEN2 & Presenilin 2 & 0.182 & -1.39857889 & -0.1595881 \\
\hline AQP1 & Aquaporin 1 & 0.367 & -0.93107284 & -0.11615238 \\
\hline
\end{tabular}

Negative $t$ values are for comparisons displaying gene changes that are increased in $A D$ relative to control (i.e. decreased in control relative to $A D$ ). The same is true for negative $\log 2 \mathrm{FC}$ values

transport, $\mathrm{HCO}_{3}{ }^{-}$production and barrier stability were downregulated in AD. Genes involved in inflammation and $A \beta$ accumulation were also upregulated in $\mathrm{AD} C \mathrm{CP}$. Altered mitochondrial enzyme and transporter expression, associated with decreased ATP production, reflects $\mathrm{AD}$-associated metabolic- and oxidation-related defects at the BCSFB. All of these changes likely contribute to decreased CSF production in $\mathrm{AD}$, though the reader must be aware that protein expression and mRNA expression are not always directly related. In addition, the reader should be aware that while fold changes are a good indicator of the magnitude of change in gene expression, they do not necessarily translate to functional significance. Specific gene expression values for each gene in control and $\mathrm{AD}$ cases would be useful for better understanding functional relevance of the gene expression changes detailed here; hence the provided Additional file 1 of all gene expression values.

Various lines of evidence suggest that $A \beta$ accumulation in $\mathrm{AD}$ is a problem of clearance rather than overproduction [30,31]. CSF production and turnover are part of the clearance mechanisms of the CNS. Communication with the extracellular fluid (ECF) space and the paravascular space $[32,33]$ allows the CSF pathway to function efficiently as a clearance pathway.

Upregulated $A \beta$ precursor protein binding family protein $\mathrm{APBA} 3$ in $\mathrm{CP}$ is consistent with plaque buildup $[33,34] . A \beta$ retention in $A D C P$ [35] and ECF favors oligomerization and deposition, weakening BCSFB tight junctions while increasing levels of inflammatory cytokines and matrix metalloproteinase [21]. A $\beta$ burden in the brain and its barriers may trigger microglia activation due to brain injury and promote reactive astrocytes. The transformation of astrocytes into neurotoxic reactive cells, through increased secretion of interleukin- $1 \alpha$, tumor necrosis factor $\alpha$, and complement $\mathrm{C} 1 \mathrm{q}$ leads to self-perpetuating, widespread neuronal death in AD [36].

Unchecked expression of inflammatory mediators in response to brain tissue damage and barrier disruption [37] increases activation of brain microglia, and promotes invasion of additional immune cells through BCSFB into CSF and brain. CP upregulation of interleukin-1 receptor (IL1R) and interleukin-1 receptor like 1 (IL1RL1) in AD coincides with increased IL-1 secretion by activated microglia. Among the cytokine families, activated IL1R promotes acute and chronic inflammation [38]. Antagonists of IL1R have potent anti-inflammatory effects [39].

Along with $\mathrm{A} \beta$ binding protein and IL1R upregulation, downregulated claudin- 5 , claudin- 11 and claudin- 18 may contribute to barrier degradation in $\mathrm{AD}$. Claudin- 5 is an important structural component of tight junction strands [40], and a gatekeeper protein regulating paracellular transport at BCSFB tight junctions [20]. Information is lacking for CP claudin-18, although high claudin-18 expression occurs in lung alveolar epithelial tight junctions [41]. Claudin-11 is an essential component of myelin, and claudin-11 null mice lack myelin sheath tight junctions [42]. Furthermore claudin-11 downregulation increases BCSFB permeability to FITC-dextran [43]. Other claudin mRNA examined did not display significant changes in AD CP.

Increased BCSFB transcellular and paracellular permeability in AD disrupts the $\mathrm{CP}-\mathrm{CSF}$ secretory, synthetic, and transportation functions [3]. CSF carries essential nutrients and ions, at homeostatic concentrations, into brain [44]. This enables CSF control of temperature, blood pressure, and $\mathrm{pH}[6]$.

In the context of ion transport and CSF formation, it is pertinent to first evaluate $\mathrm{CP}$ mitochondria in $\mathrm{AD}$. AD hippocampal and $\mathrm{CP}$ cells are deficient in the 
mitochondrial enzyme cytochrome c oxidase, complex IV of the electron transport chain [45]. Mitochondrial dysfunction also links to autophagy in AD. This inability to degrade defective macromolecules and organelles links with harmful neuronal lipofuscin buildup [46]. Excess lipofuscin in aging and in the AD CP is problematic for $\mathrm{A} \beta$ plaque formation $[47,48]$.

The key enzyme for ATP synthesis is mitochondrial ATP synthase. Choroidal ATP synthase damage indicates depressed ATP synthesis in AD. Even if ion transporters are intact, active transporters function inefficiently with diminished ATP (e.g., $\mathrm{Na}-\mathrm{K}$ ATPase, an important route for Na efflux from CPE [14], requires ATP hydrolysis for $\mathrm{Na}-\mathrm{K}$ exchange). Thus an important consequence of alterations in ATP synthase subunit and assembly factor expression may be disrupted ATP-dependent active transport of solutes across CPE-CSF in AD, leading to impaired solute concentration gradients that are integral for CSF production. Turning to specific ion transporters, $\mathrm{Na}-\mathrm{K}$-ATPase is a heterodimer of an $\alpha$ and $\beta$ subunit. Four $\alpha$ subunits and three $\beta$ subunits exist in mammals [49]. Na-K ATPase is at the apical CPE and CSF secretion is reduced by inhibiting $\mathrm{Na}-\mathrm{K}-\mathrm{ATPase}$ [26]. This is predictable given the $\mathrm{Na}-\mathrm{K}$-ATPase role in primary active $\mathrm{Na}^{+}$secretion into CSF (and $\mathrm{K}^{+}$removal from CSF). ATP1A1, found to be the dominant catalytic subunit of the Na-K ATPase in mouse studies [50], was mildly upregulated in $\mathrm{AD} C \mathrm{CP}$ while other lesser-expressed subunits ATP1A2 and ATP1B1 were downregulated. Upregulation of ATP1A1 in AD CP, if it is the same in humans, by itself would suggest increased $\mathrm{Na}-\mathrm{K}$ pumping and increased CSF production. However, given decreased CSF production in AD [1], the contribution of the $\mathrm{Na}-\mathrm{K}$ ATPase may not be as relevant as other solute transporters in CSF production disturbances in AD.

The $\mathrm{Na}-\mathrm{K}-\mathrm{Cl}$ cotransporter NKCC1, encoded by the SLC12A2, has an important role in solute transport. NKCC1 is at the apical CPE [51]. Steffensen and colleagues [52] suggest that NKCC1 is responsible for $\sim 50 \%$ of CSF production. This finding attributes a central role for NKCC1 in enabling $\mathrm{H}_{2} \mathrm{O}$ to flow from CPE to CSF. Earlier theories proposed a simple osmotic model of NKCC1 coupling to an aquaporin $[53,54]$. We observed no significant change in AQP1 and AQP4 in AD CP. However, CSF production declines by $\sim 20 \%$ in AQP1 knockout (KO) mice [16], different from the $\sim 50 \%$ suggested by Steffensen et al. who theorized that $\mathrm{H}_{2} \mathrm{O}$ accompanies ion flux directly through NKCC1 [52]. Considering the likely role of NKCC1 to facilitate $\mathrm{H}_{2} \mathrm{O}$ flow for CSF production, decreased NKCC1 mRNA in AD versus control CP agrees with generallydecreased CSF production and impaired CSF dynamics measured in AD [1]. We conclude that CSF dynamics diminution in $\mathrm{AD}$ is not mainly attributable to reduced aquaporin expression. Therefore, by deduction, altered $\mathrm{H}_{2} \mathrm{O}$ movement across CPE in AD is more likely related to lower NKCC1 mRNA (Table 1). Still, further analysis of NKCC1 transcript vs. protein expression in CP is needed to reconcile disparate findings [55] for AD.

Bicarbonate transport across CPE sustains CSF production [56]. Many transporters utilize $\mathrm{HCO}_{3}$ gradients to move cations and anions into and out of CPE. Acetazolamide inhibition of $\mathrm{CA}$ distorts $\mathrm{pH}$ gradients among CPE, CSF and brain [29]. In addition, Vogh and colleagues established that CA inhibitors reduce CSF production by $>50 \%$ [57]. This suggests a sizeable portion of CSF production depends on cell-produced $\mathrm{HCO}_{3}$.

$\mathrm{Na}$-dependent $\mathrm{Cl}-\mathrm{HCO}_{3}$ exchange by CP SLC4A10 gene is at the basolateral face. SLC4A10 mediates influx of a $\mathrm{Na}^{+}$and $\mathrm{HCO}_{3}$ ion per efflux (into CP interstitium) of one $\mathrm{Cl}^{-}$ion [26]. SLC4A10 KO mice showed decreased ventricular volume, likely from reduced CSF production [58]. There was also microvilli attenuation and CPE cell enlargement in SLC4A10 KO mice. Given this study, loss of SLC4A10 in AD would be expected to depress CSF production. The $\mathrm{Na}-\mathrm{HCO}_{3}$ cotransporter SLC4A5, downregulated in AD, is in apical CPE. There it mediates transport of three $\mathrm{HCO}_{3}$ and one $\mathrm{Na}^{+}$from CPE into CSF. This stoichiometry/vector supports a $\mathrm{Na}-\mathrm{HCO}_{3}$ role to counter CSF acidity while promoting CSF formation [59]. SLC4A5 KO mice results resembled SLC4A10 KO mice in one study: decreased lateral ventricular volume, reduced intracranial pressure, and altered CPE structure [60]. However, a second SLC4A5 study, utilizing a different $\mathrm{KO}$ mouse, caused arterial hypertension but no altered ventricular volume [61] Further research needs to clarify the CSF-supporting role of SLC4A5, although like SLC4A10, decreased expression intimates reduced CSF production in AD.

Essential to $\mathrm{HCO}_{3}$ transport is carbonic anhydrase activity. CA2, CA3, and CA4 were downregulated in AD. CA13, though, was upregulated. The CA's generate $\mathrm{HCO}_{3}$ and $\mathrm{H}^{+}$ions from $\mathrm{H}_{2} \mathrm{O}$ and $\mathrm{CO}_{2}[26,29]$. CA2, $\mathrm{CA} 3$ and CA13 are cytosolic while CA4 is tethered by a membrane anchor [62]. Of particular significance with respect to $\mathrm{AD}$ and CSF dynamics is the CA isoform CA2, due to its high catalytic activity and efficacy in proton shuttling [63]. High rates of $\mathrm{HCO}_{3}$ production by $\mathrm{CA} 2$ allow regulation of blood $\mathrm{pH}$ to preserve homeostasis. In kidneys, CA2 and CA4 associate with $\mathrm{HCO}_{3}$-anion transporters and proton antiporters, directly coupling $\mathrm{HCO}_{3}$-synthesis to ion exchange [62]. If a parallel system exists in $\mathrm{CP}$, any downregulated CA2 and CA4 in AD CP would directly disrupt the action of $\mathrm{HCO}_{3}$-anion transporters, decreasing active solute transport and depressing CSF formation. 
A limitation of this study is the focus on pathways we considered important for CSF production and the structural integrity of the CP. We therefore did not examine every gene in the Brown-Merck GEO database that possibly impacts CSF production. Unknown genes omitted by us may be found by others in future CSF dynamics analyses to be important. In an earlier study, Bergen et al. analyzed gene expression profiles of control and AD subjects based on RNA extracted from laser-dissected CPE cells [20]. Mining of their database may yield additional new insights. Comparison of their data with ours was not possible due to methodological differences. However, Stopa et al. analyzed common gene transcripts controlling CSF dynamics/homeostasis in both databases: Netherlands versus Brown-Merck. They reported 70\% agreement, isolated CPE versus CP tissue, with Bergen et al. [20, 24].

\section{Conclusions}

We identified multiple genes involved in CSF production that differed in expression between $\mathrm{AD}$ and control CP. Many ion transporters that impact solute and $\mathrm{H}_{2} \mathrm{O}$ transport and fluid dynamics were downregulated in AD. Importantly for many choroid epithelial processes, F0F1 ATP synthase was downregulated; this fits a diminished energy supply for choroidal transport. Genes that maintain $\mathrm{CP}$ membrane tight junctions had decreased expression. Upregulated $\mathrm{CP}$ genes in AD included those mediating chronic inflammation and neurodegeneration. Each altered gene transcript in this study is a potential candidate to explain the altered CSF production observed clinically in AD. Demonstration of causal relationships may lead to new therapeutic targets for AD aimed at bolstering CSF production and turnover.

\section{Additional file}

Additional file 1. Gene expression values.

\section{Abbreviations}

A $\mathrm{B}$ : amyloid beta; AD: Alzheimer's disease; APP: amyloid precursor protein; AQP1: aquaporin 1; ATP: adenosine triphosphate; BBB: blood-brain barrier; BCSFB: blood-CSF barrier; CA: carbonic anhydrase; CLDN: claudin; Cq1: complement factor q1; CSF: cerebrospinal fluid; CP: choroid plexus; CPE: choroid plexus epithelium: GEO: Gene Expression Omnibus; IL-1: interleukin-1: KCC: potassium-chloride cotransporter; KO: knockout; NKCC: sodium-potassiumchloride cotransporter; RNA: ribonucleic acid; SLC: solute carrier; TNFa: tumor necrosis factor alpha; TTR: transthyretin.

\section{Authors' contributions}

All authors SK, ES, CJ, AB, and GS contributed to the experimental design, data analysis and manuscript preparation and review. All authors read and approved the final manuscript.

\section{Author details}

1 Department of Pathology (Neuropathology Division), Warren Alpert Medical School at Brown University, Providence, RI 02903, USA. ${ }^{2}$ Department of Neurosurgery, Warren Alpert Medical School at Brown University, Providence, RI 02903, USA. ${ }^{3}$ Department of Surgery, University of California San Diego, La Jolla, CA, USA. ${ }^{4}$ Department of Neurosurgery, Stanford University, 710 Frenchmans Rd, Stanford, CA 94305, USA.

\section{Acknowledgements}

The authors thank the families of patients with Alzheimer's disease, referred from the Department of Neurology at Rhode Island Hospital, for donating patient brains to the Brown University Brain Tissue for Neurodegenerative Disorders Resource Center.

\section{Competing interests}

The authors declare that they have no competing interests. GDS has a financial interest in a startup company dedicated to AD treatment. That company did not support this research in any way, nor will this research benefit the company in any way.

\section{Availability of data and materials}

The datasets analyzed are available under the Gene Expression Omnibus (GEO) Accession GSE110226 at the National Center for Biotechnology Information (NCBI) at the National Library of Medicine, National Institutes of Health.

\section{Consent for publication}

All authors agree with publication of this manuscript.

\section{Ethics approval and consent to participate}

This research was approved by the Institutional Review Board for Clinical Research at RI Hospital.

\section{Funding}

This study was supported by funds provided by the Division of Neuropathology at Rhode Island Hospital (for CP tissue data analysis and manuscript costs).

\section{Publisher's Note}

Springer Nature remains neutral with regard to jurisdictional claims in published maps and institutional affiliations.

Received: 11 September 2018 Accepted: 3 December 2018 Published online: 12 December 2018

\section{References}

1. Silverberg GD, Heit G, Huhn S, Jaffe RA, Chang SD, Bronte-Stewart H, et al. The cerebrospinal fluid production rate is reduced in dementia of the Alzheimer's type. Neurology. 2001;57:1763-6. https://doi.org/10.1212/ WNL.57.10.1763.

2. Silverberg GD, Mayo M, Saul T, Rubenstein E, McGuire D. Alzheimer's disease, normal-pressure hydrocephalus, and senescent changes in CSF circulatory physiology: a hypothesis. Lancet Neurol. 2003;2:506-11.

3. Serot JM, Béné MC, Faure GC. Choroid plexus, aging of the brain, and Alzheimer's disease. Front Biosci. 2003:8:s515-21.

4. Wostyn P, van Dam D, Audenaert K, de Deyn PP. Genes involved in cerebrospinal fluid production as candidate genes for late-onset Alzheimer's disease: a hypothesis. J Neurogenet. 2011;25:195-200. https://doi. org/10.3109/01677063.2011.620191 (Epub 2011 Oct 24).

5. Serot JM, Zmudka J, Jouanny P. A possible role for CSF turnover and choroid plexus in the pathogenesis of late onset Alzheimer's disease. J Alzheimers Dis. 2012;30:17-26. https://doi.org/10.3233/jad-2012-111964.

6. Johanson C, Johanson NA. Choroid plexus blood-CSF barrier: major player in brain disease modeling and neuromedicine. J Neurol Neuromed. 2018:3:39-58.

7. Sakka L, Coll G, Chazal J. Anatomy and physiology of cerebrospinal fluid. Eur Ann Otorhinolaryngol Head Neck Dis. 2011;128:309-16. https://doi. org/10.1016/j.anorl.2011.03.002

8. Johanson CE, Duncan JA, Klinge PM, Brinker T, Stopa EG, Silverberg GD. Multiplicity of cerebrospinal fluid functions: new challenges in health and disease. Cerebrospinal Fluid Res. 2008;5:10. https://doi. org/10.1186/1743-8454-5-10. 
9. Pollay M, Stevens FA, Roberts PA. Alteration in choroid-plexus blood flow and cerebrospinal- fluid formation by increased ventricular pressure. Neurobiol CSF. 1983;2:687-95. https://doi.org/10.1007/978-1-4615-9269-3_43.

10. Damkier HH, Nielsen S, Praetorius J. Molecular expression of SLC4derived $\mathrm{Na}$-dependent anion transporters in selected human tissues. Am J Physiol Regul Integr Comp Physiol. 2007;293:R2136-46. https://doi. org/10.1152/ajpregu.00356.2007 (Epub 2007 Aug 22).

11. Johanson CE, Murphy VA. Acetazolamide and insulin alter choroid plexus epithelial cell [Na+], pH, and volume. Am J Physiol. 1990;258(6 Pt 2):F1538-46.

12. Millar ID, Bruce JI, Brown PD. Ion channel diversity, channel expression and function in the choroid plexuses. CSF Res. 2007;4(1):8. https://doi. org/10.1186/1743-8454-4-8.

13. Smith QR, Johanson CE. Effect of ouabain and potassium on ion concentrations in the choroidal epithelium. Am J Physiol. 1980;238(5):F399-406. https://doi.org/10.1152/ajprenal.1980.238.5.f399.

14. Pollay M, Hisey B, Reynolds E, Tomkins P, Stevens FA, Smith R. Choroid plexus $\mathrm{Na} / \mathrm{K}$-activated adenosine triphosphatase and cerebrospinal fluid formation. Neurosurgery. 1985;17:768-72. https://doi.org/10.1097/00006 123-198511000-00007.

15. Bairamian D, Johanson CE, Parmelee JT, Epstein MH. Potassium cotransport with sodium and chloride in the choroid plexus. J Neurochem. 1991;56:1623-9.

16. Oshio K, Watanabe H, Song Y, Verkman AS, Manley GT. Reduced cerebrospinal fluid production and intracranial pressure in mice lacking choroid plexus water channel Aquaporin-1. FASEB. 2005;19:76-8. https://doi. org/10.1096/fj.04-1711fje.

17. Montagne A, Zhao Z, Zlokovic B. Alzheimer's disease: a matter of bloodbrain barrier dysfunction? J Exp Med. 2017;214:3151-69. https://doi. org/10.1084/jem.201714068.

18. Silverberg GD, Miller MC, Messier AA, Majmudar S, Machan JT, Donahue $\mathrm{JE}$, et al. Amyloid deposition and influx transporter expression at the blood-brain barrier are increased in normal aging. J Neuropath Exp Neurol. 2010;69:98-108. https://doi.org/10.1097/NEN.0b013e3181c8ad2f.

19. Silverberg GD, Messier AA, Miller MC, Machan JT, Majmudar SS, Stopa EG, et al. Amyloid efflux transporter expression at the blood-brain barrier declines in normal aging. J Neuropath Exp Neurol. 2010;69:1034-43. https://doi.org/10.1097/nen.0b013e3181f46e25.

20. Bergen AA, Kaing S, Brink JB, Gorgels TG, Janssen SF. Gene expression and functional annotation of human choroid plexus epithelium failure in Alzheimer's disease. BMC Genomics. 2015;16(16):956. https://doi. org/10.1186/s12864-015-2159-z.

21. Brkic M, Balusu S, Wonterghem EV, Gorle N, Benilova I, Kremer A, Vandenbroucke RE. Amyloid oligomers disrupt blood-CSF barrier integrity by activating matrix metalloproteinases. J Neurosci. 2015;35:12766-78. https ://doi.org/10.1523/jneurosci.0006-15.2015.

22. Silverberg G, Mayo M, Saul T, Fellman J, McGuire D. Elevated cerebrospinal fluid pressure patients with Alzheimer's disease. Cerebrospinal Fluids Res. 2006;3:7. https://doi.org/10.1186/1743-8454-3-7.

23. Fujiyoshi M, Ohtsuki S, Hori S, Tachikawa M, Terasaki T. 24S-hydroxycholesterol induces cholesterol release from choroid plexus epithelial cells in an apical- and apoE isoform-dependent manner concomitantly with the induction of ABCA1 and ABCG1 expression. J Neurochem. 2007;100:96878. https://doi.org/10.1111/j.1471-4159.2006.04240.x.

24. Stopa EG, Tanis KQ, Miller MC, Nikonova EV, Podtelezhnikov AA, Finney EM, Johanson CE. Comparative transcriptomics of choroid plexus in Alzheimer's disease, frontotemporal dementia and Huntington's disease: implications for CSF homeostasis. Fluids Barriers CNS. 2018;15:18. https:// doi.org/10.1186/s12987-018-0102-9.

25. Ho HT, Dahlin A, Wang J. Expression profiling of solute carrier gene families at the blood-CSF barrier. Front Pharmacol. 2012;3:154. https://doi. org/10.3389/fphar.2012.00154b.

26. Brown P, Davies S, Speake T, Millar I. Molecular mechanisms of cerebrospinal fluid production. Neuroscience. 2004;129:955-68. https://doi. org/10.1016/j.neuroscience.2004.07.003.

27. McCarthy KD, Reed DJ. The effect of acetazolamide and furosemide on cerebrospinal fluid production and choroid plexus carbonic anhydrase activity. J Pharmacol Exp Ther. 1974;189:194-201.

28. Christensen HL, Barbuskaite D, Rojek A, Malte H, Christensen IB, Füchtbauer AC, Damkier HH. The choroid plexus sodium-bicarbonate cotransporter NBCe2 regulates mouse cerebrospinal fluid pH. J Physiol. 2018;596:4709-47028. https://doi.org/10.1113/jp275489.

29. Johanson CE. Differential effects of acetazolamide, benzolamide and systemic acidosis on hydrogen and bicarbonate gradients across the apical and basolateral membranes of the choroid plexus. J Pharmacol Exp Ther. 1984;231:502-11.

30. Selkoe DJ. Toward a comprehensive theory for Alzheimer's disease. Hypothesis: Alzheimer's disease is caused by the cerebral accumulation and cytotoxicity of amyloid beta-protein. Ann NY Acad Sci. 2000;924:17-25.

31. Hardy J. A hundred years of Alzheimer's disease research. Neuron. 2006;52:3-13.

32. Iliff JJ, Wang M, Liao Y, Plogg BA, Peng W, Gundersen GA, Nedergaard M. A paravascular pathway facilitates CSF flow through the brain parenchyma and the clearance of interstitial solutes, including amyloid. Sci Transl Med. 2012;4(147):147ra111. https://doi.org/10.1126/scitranslmed.3003748.

33. de Leon MJ, Li Y, Okamura N, Tsui WH, Saint-Louis LA, Glodzik L, Rusinek $\mathrm{H}$. Cerebrospinal fluid clearance in Alzheimer disease measured with dynamic PET. J Nuclear Med. 2017;58:1471-6. https://doi.org/10.2967/ jnumed.116.187211.

34. Tanahashi H, Tabira T. Genomic organization of the human X11L2 gene (APBA3), a third member of the $\mathrm{X} 11$ protein family interacting with Alzheimer's $\beta$-amyloid precursor protein. NeuroReport. 1999;10:2575-8. https://doi.org/10.1097/00001756-199908200-00025.

35. González-Marrero I, Giménez-Llort L, Johanson CE, Carmona-Calero EM, Castañeyra-Ruiz L, Brito-Armas JM, et al. Choroid plexus dysfunction impairs beta-amyloid clearance in a triple transgenic mouse model of Alzheimer's disease. Front Cell Neurosci. 2015;9:17. https://doi. org/10.3389/fncel.2015.00017.

36. Liddelow SA, Guttenplan KA, Clarke LE, Bennett FC, Bohlen CJ, Schirmer $L$, et al. Neurotoxic reactive astrocytes are induced by activated microglia. Nature. 2017;541:481-7. https://doi.org/10.1038/nrneurol.

37. Schwartz M, Deczkowska A. Neurological disease as a failure of brainimmune crosstalk: the multiple faces of neuroinflammation. Trends Immunol. 2016;37:668-79. https://doi.org/10.1016/j.it.2016.08.001.

38. Dinarello CA. Interleukin-1 in the pathogenesis and treatment of inflammatory diseases. Blood. 2011;117:3720-32. https://doi.org/10.1182/blood -2010-07-273417.

39. Singh N, Hopkins SJ, Hulme S, Galea JP, Hoadley M, Vail A, et al. The effect of intravenous interleukin-1 receptor antagonist on inflammatory mediators in cerebrospinal fluid after subarachnoid haemorrhage: a phase II randomised controlled trial. J Neuroinflamm. 2014;11:1. https://doi. org/10.1186/1742-2094-11-1.

40. Redzic Z. Molecular biology of the blood-brain and the blood-cerebrospinal fluid barriers: similarities and differences. Fluids Barriers CNS 2011;8(1):3. https://doi.org/10.1186/2045-8118-8-3.

41. Kotton DN. Claudin-18: unexpected regulator of lung alveolar epithelial cell proliferation. J Clin Invest. 2018;128:903-5. https://doi.org/10.1172/ jci99799.

42. Gow A, Southwood CM, Li JS, Pariali M, Riordan GP, Brodie SE, et al. CNS myelin and sertoli cell tight junction strands are absent in osp/claudin-11 null mice. Cell. 1999;599:649-59. https://doi.org/10.1016/s0092 -8674(00)81553-6.

43. Uchida Y, Sumiya T, Tachikawa M, Yamakawa T, Murata S, Yagi Y, et al. Involvement of claudin-11 in disruption of blood-brain, -spinal cord, and -arachnoid barriers in multiple sclerosis. Mol Neurobiol. 2018. https://doi. org/10.1007/s12035-018-1207-5.

44. Wright BL, Lai JT, Sinclair AJ. Cerebrospinal fluid and lumbar puncture: a practical review. J Neurol. 2012;259:1530-45. https://doi.org/10.1007/ s00415-012-6413-x

45. Cottrell D, Blakely E, Johnson M, Ince P, Turnbull D. Mitochondrial enzyme-deficient hippocampal neurons and choroidal cells in AD. Neurology. 2001;157:260-4. https://doi.org/10.1212/wnl.57.2.260.

46. Moreira PI, Carvalho C, Zhu X, Smith MA, Perry G. Mitochondrial dysfunction is a trigger of Alzheimers disease pathophysiology. Biochim Biophys Acta. 2010;1802:2-10. https://doi.org/10.1016/j.bbadis.2009.10.006.

47. Serot JM, Bene MC, Faure GC. Comparative immunohistochemical characteristics of human choroid plexus in vascular and Alzheimers dementia. Hum Pathol. 1994;25:1 185-90. https://doi.org/10.1016/00468177(94)90035-3. 
48. Dowson JH. Neuronal lipofuscin accumulation in ageing and Alzheimer dementia: a pathogenic mechanism? Br J Psychiatry. 1982;140:142-8. https://doi.org/10.1192/bjp.140.2.142.

49. Scheiner-Bobis G. The sodium pump. Eur J Biochem. 2002;269:2424-33. https://doi.org/10.1046/j.1432-1033.2002.02909.x.

50. Zlokovic BV, Mackic JB, Wang L, McComb JG, McDonough A. Differential expression of $\mathrm{Na}$, K-ATPase alpha and beta subunit isoforms at the bloodbrain barrier and the choroid plexus. J Biol Chem. 1993;268:8019-25.

51. Keep RF, Xiang J. Choroid plexus potassium cotransport: modulation by osmotic stress and external potassium. J Neurochem. 1995;64:2747-54. https://doi.org/10.1046/j.1471-4159.1995.64062747.x

52. Steffensen AB, Oernbo EK, Stoica A, Gerkau NJ, Barbuskaite D, Tritsaris K, Macaulay N. Cotransporter-mediated water transport underlying cerebrospinal fluid formation. Nat Commun. 2018;9:2167. https://doi. org/10.1038/s41467-018-04677-9

53. Praetorius J, Damkier HH. Transport across the choroid plexus epithelium. Am J Physiol-Cell Physiology. 2017;312:C673-86. https://doi.org/10.1152/ ajpcell.00041.2017.

54. Hladky SB, Barrand MA. Fluid and ion transfer across the blood-brain and blood-cerebrospinal fluid barriers; a comparative account of mechanisms and roles. Fluids Barriers CNS. 2016. https://doi.org/10.1186/s1298 7-016-0040-3

55. Oshio K, Song Y, Verkman AS, Manley GT. Aquaporin-1 deletion reduces osmotic water permeability and cerebrospinal fluid production. Acta Neurochir Suppl. 2003;86:525-8. https://doi. org/10.1007/978-3-7091-0651-8_107.

56. Saito Y, Wright EM. Regulation of bicarbonate transport across the brush border membrane of the bull-frog choroid plexus. J Physiol. 1984;350:327-42. https://doi.org/10.1113/jphysiol.1984.sp015204.
57. Vogh BP, Godman DR, Maren TH. Effect of AlCl3 and other acids on cerebrospinal fluid production: a correction. J Pharmacol Exp Ther. 1987:243:33-9.

58. Jacobs S, Ruusuvuori E, Sipila ST, Haapanen A, Damkier HH, Kurth I, et al Mice with targeted SIc4a10 gene disruption have small brain ventricles and show reduced neuronal excitability. Proc Nat Acad Sci. 2007;105:3116. https://doi.org/10.1073/pnas.0705487105.

59. Christensen HL, Nguyen AT, Pedersen FD, Damkier HH. Na dependent acid-base transporters in the choroid plexus; insights from slc4 and slc9 gene deletion studies. Front Physiol. 2013;4:304. https://doi.org/10.3389/ fphys.2013.00304.

60. Kao L, Kurtz LM, Shao X, Papadopoulos MC, Liu L, Bok D, et al. Severe neurologic impairment in mice with targeted disruption of the electrogenic sodium bicarbonate cotransporter NBCe2 (SIc4a5Gene). J Biol Chem. 2011;286:32563-74. https://doi.org/10.1074/jbc.m111.249961.

61. Gröger N, Vitzthum H, Fröhlich H, Krüger M, Ehmke H, Braun T, et al. Targeted mutation of SLC4A5 induces arterial hypertension and renal metabolic acidosis. Hum Mol Genet. 2012;21:1025-36. https://doi.org/10.1093/ hmg/ddr533.

62. Purkerson J, Schwartz G. The role of carbonic anhydrases in renal physiology. Kidney Internat. 2007;71:103-15. https://doi.org/10.1038/sj.ki.50020 20.

63. Pinard MA, Mahon B, Mckenna R. Probing the surface of human carbonic anhydrase for clues towards the design of isoform specific inhibitors. Biomed Res Int. 2015;2015:453543. https://doi.org/10.1155/2015/453543.
Ready to submit your research? Choose BMC and benefit from:

- fast, convenient online submission

- thorough peer review by experienced researchers in your field

- rapid publication on acceptance

- support for research data, including large and complex data types

- gold Open Access which fosters wider collaboration and increased citations

- maximum visibility for your research: over 100M website views per year

At BMC, research is always in progress.

Learn more biomedcentral.com/submissions 